\title{
Expression of immunoglobulin-like transcript (ILT)2 and ILT3 in human gastric cancer and its clinical significance
}

\author{
YI ZHANG ${ }^{1}$, NAN LU $^{2}$, YUWEN XUE ${ }^{3}$, MIN ZHANG $^{4}$, YINGJIE LI $^{1}$, YUANQUAN SI $^{1}$, \\ XIAOKUN BIAN $^{1}$, YANFEI JIA ${ }^{5}$ and YUNSHAN WANG ${ }^{5}$
}

\author{
${ }^{1}$ Department of Clinical Laboratory Medicine, Qilu Hospital of Shandong University; ${ }^{2}$ Institute of Diagnostics, School of \\ Medicine, Shandong University; ${ }^{3}$ Department of Medicine, Qilu Hospital of Shandong University; ${ }^{4}$ Department of Medicine, \\ Shandong Chest Hospital; ${ }^{5}$ Shandong Province Key Laboratory for Tumor Target Molecules, Medical Research and \\ Laboratory Diagnostic Center, Jinan Central Hospital Affiliated to Shandong University, Jinan, P.R. China
}

Received August 11, 2011; Accepted December 5, 2011

DOI: $10.3892 / \mathrm{mmr} .2012 .744$

\begin{abstract}
Immune inhibitory receptors play an important role in organ transplantation, autoimmune diseases and cancers. Immunoglobulin-like transcript (ILT)2 and ILT3 belong to the inhibitory receptors of the ILT family, which have been reported to regulate a broad range of cellular functions involved in the immune response. They contain immunoreceptor tyrosine-based inhibitory motifs (ITIMs), which are related to immune regulation. Although ILT receptors have been studied in dendritic cells (DCs), T cells, NK cells and other cell types, the expression and clinical significance of ILT2 and ILT3 in gastric cancer have yet to be elucidated. Here, the expression of ILT2 and ILT3 in gastric cancer cell lines and pathologic tissues, as well as their effects on the cytotoxicity of NK92MI against the gastric cancer cell lines MKNI with ILT2 ${ }^{\text {low }}$ ILT $3^{\text {low }}$ and HGC-27 with ILT2 ${ }^{\text {high }}$ ILT $3^{\text {high }}$ were detected. The results suggest that ILT2 and ILT3 are expressed with diverse degrees in gastric cancer cells and tissues, and the expression of ILT2 is related with differentiation and size of tumors. Furthermore, the cytotoxic activity of NK92MI against the MKNI cell line was stronger than that against HGC-27. This study indicates that ILT2 and ILT3 play a key role in gastric cancer immune escape, and ILT2 may be a new target in the clinical diagnosis and treatment of gastric cancer.
\end{abstract}

Correspondence to: Professor Yi Zhang, Department of Clinical Laboratory Medicine, Qilu Hospital of Shandong University, 107 Wen Hua Road, Jinan 250012, P.R. China

E-mail: yizhang@sdu.edu.cn

Professor Yunshan Wang, Medical Research and Laboratory Diagnostic Center, Jinan Central Hospital Affiliated to Shandong University, 115 Jie Fang Road, Jinan 250013, P.R. China

E-mail: sdjnwys@163.com

Key words: immunoglobulin-like transcript 2, immunoglobulinlike transcript 3, gastric cancer, NK cells

\section{Introduction}

Gastric cancer is one of the most serious diseases threatening human health. It is the fourth most common cancer and the second leading cause of cancer-related death in the world $(1,2)$. According to the Chinese Ministry of Health in 2006, over 400,000 new cases of gastric cancer are diagnosed and approximately 300,000 deaths in China are reported each year.

Interaction between the host immune response and gastric cancer cells results in the occurrence and development of gastric cancer. This involves multilateral factors, such as host effector cells, stromal cells and tumor cells (3-5). Shortage of co-stimulation molecules on the surface of tumor cells is the main reason for immune evasion among all of the factors. There are two types of co-stimulation molecules discovered at present, which include positive and negative co-stimulation molecules. The former influences the activation and proliferation of T lymphocytes and secretion of cytokines by combining with lymphocyte receptors, while the latter induces T cells anergy through two ways as follows. One is to induce inhibitory factors to express on the effector cells and the other is to elicit them to express on tumor cells (6).

Immunoglobulin-like transcripts (ILTs), also called leukocyte immunoglobulin-like receptors (LIRs/LILRs) or CD85 (7), are a group of membrane receptors coded by more than 10 genes located on the $19 \mathrm{q} 13.4$ chromosome $(8,9)$. Nakajima et al (10) identified a new class of immunoglobulin superfamily, whose members were named ILT1 and ILT2, and other ILT family members were later found and identified (11-14). Characterized by different transmembrane and cytoplasmic domains, the members of the ILT family are divided into activating receptors, inhibitory receptors and soluble receptors (15). ILT2 and ILT3 as the two primary types of inhibitory receptors, which regulate the functions of cells involved in the immune system (16). ILT2 is detected on the surface of a proportion of NK cells $(\sim 75 \%)$ and T lymphocytes (4-20\%), on all B lymphocytes, monocytes, DCs and macrophages (17). However, ILT3 is expressed only on monocytes, DCs and endothelial cells, but not on T and B lymphocytes $(18,19)$. They play an extensive role by transmitting inhibitory signals, for instance, they restrain the killer activity of 
killer cells, and regulate signal transmission between DCs and T lymphocytes (20-23). ILT3 also induces the generation of $\mathrm{CD}^{+} \mathrm{T}$ suppressor cells and renders antigen-presenting cells tolerogenic $(22,24)$. In addition, it has been reported that ILT2 and ILT3 integrate with MHC-I molecules, especially HLA-G, and deliver negative signals by immunoreceptor tyrosinebased inhibitory motifs (ITIM) to repress the activation of $\mathrm{CD}^{+}$and $\mathrm{CD}^{+} \mathrm{T}$ lymphocytes and down-regulate recognition of antigens by $\mathrm{CD}^{+} \mathrm{T}$ lymphocytes, which leads to the immune escape of tumor cells (25-27).

The mechanisms through which tumor cells escape from host immunity are not yet clear. However, one important reasons is that ILTs induce immunological tolerance. Lefebvre et al (28) discovered that partial tumor infiltrating lymphocytes in human breast cancer express ILT2. Yet, the role of ILT receptors in tumors is not clear and many issues require further study. Our research aimed to investigate the expression and role of ILT2 and ILT3 in gastric cancer via in vivo and in vitro experiments.

\section{Materials and methods}

Cell lines and culture. Six human gastric cancer cell lines were used, which included the well-differentiated gastric cancer cell line MKNI, moderately differentiated cell lines SGC7901 and AGS, the poorly differentiated cell line MGC803 and undifferentiated cell lines HGC27 and BCG823, respectively. Human NK92MI cells were used as effector cells. All gastric cancer cell lines and human NK92MI were from Shandong Province Key Laboratory for Tumor Target Molecules in Jinan Central Hospital which is affiliated to Shandong University. All cell lines were maintained in RPMI-1640 or F-12 medium (Gibco Co., USA) supplemented with $10 \%$ heat-inactivated fetal calf serum (FCS), $100 \mathrm{IU} / \mathrm{ml}$ penicillin and $100 \mathrm{IU} / \mathrm{ml}$ streptomycin at $37^{\circ} \mathrm{C}$ in a humidified atmosphere with $5 \% \mathrm{CO}_{2}$.

Patients and information. Tumor specimens were obtained from 50 primary gastric cancer patients (37 men and 13 women; aged 38-76 years; mean age, 53.3 years) without having received any preoperative therapy at Qilu Hospital of Shandong University, China, between February, 2008 and August, 2009. The main clinicopathological variables of the patients are recorded in Tables I and II. According to pathological Tumor-Node-Metastasis International System and Lauren classification, 31 cases were characterized as gastric adenocarcinomas, 10 were mucinous adenocarcinomas and 9 were signet ring cell cancers. Considering pathological grading, 20 were staged as well differentiated and 30 as poorly differentiated. Two-thirds of the patients with lymph node metastasis were validated by conventional postoperative pathological examination. There were 19 cases with tumor size $>5 \mathrm{~cm}$, and 31 cases with tumor size $<5 \mathrm{~cm}$. We obtained informed consent from each patient, and the study protocol was approved by the Ethics Committee of Qilu Hospital of Shandong University and was performed in accordance with the ethical standards of the 2000 Declaration of Helsinki as well as the Declaration of Istanbul 2008.

Total-RNA isolation and RT-PCR. The gastric cancer cells $\left(3-5 \times 10^{5}\right)$ with various degrees of differentiation were collected respectively, and the total-RNA was extracted using the TRIzol RNA isolation kit (Invitrogen, USA). Total-RNA (1 $\mu \mathrm{g})$ was reverse transcribed using High-Capacity cDNA reverse transcription kits (Applied Biosystems, USA) according to the manufacturer's instructions and then was detected by SYBRGreen I (Invitrogen) real-time PCR. The ILT primers were synthesized by Sangon Biological Engineering Technology and Services Co., Ltd. (Shanghai, China). The primers for ILT2, ILT3 and ACTB (internal control) were designed as follows: ILT2 primer, forward, 5'-GGGGTTGTGATCGGCATCTT and reverse sequence, 5'-CTGGCCTGGACTCGATGTC; ILT3 primer, forward, 5'-CATCCATGACAGAGGACTATGC and reverse sequence, 5'-GGGCTGAAAGGGTGGGTTTA; ACTB forward, 5'-TTGCCGACAGGATGCAGAA and reverse sequence, 5'-GCCGATCCACACGGAGTACT. The lengths of the amplified fragments were 189, 311 and $101 \mathrm{bp}$, respectively. The FQ-PCR system contained SYBR-Green I $10 \mu \mathrm{l}$, PCR forward and reverse primers $(5 \mu \mathrm{M}) 1 \mu \mathrm{l}$, respectively, cDNA $2 \mu \mathrm{l}, \mathrm{ddH}_{2} \mathrm{O} 6 \mu \mathrm{l}$. There were $2 \mu \mathrm{l}$ DEPC in the negative control instead of cDNA. The reaction was incubated for 40 cycles at $95^{\circ} \mathrm{C}$ for $10 \mathrm{sec}, 60^{\circ} \mathrm{C}$ for $10 \mathrm{sec}$ and $72^{\circ} \mathrm{C}$ for $10 \mathrm{sec}$.

Flow cytometry. We collected and counted the gastric cancer cells in the media which were in the logarithmic phase, and adjusted the consistency of the cells to $1-2.5 \times 10^{5}$ cells $/ \mathrm{ml}$. The cells were washed twice with phosphate-buffered saline (PBS, $\mathrm{pH}$ 7.4), and incubated with mouse anti-human ILT2 (R\&D, USA; clone 292305) and ILT3 antibody (R\&D; clone 293623) for $30 \mathrm{~min}$. After washing thoroughly with PBS, the cells were stained with PE-labeled goat anti-mouse antibodies (R\&D) for $30 \mathrm{~min}$ at $4^{\circ} \mathrm{C}$. Cells were washed twice with PBS and analyzed by FACSCalibur flow cytometry with CellQuest software and associated software (BD Company, USA). Meanwhile, non-specific staining was determined using control goat immunoglobin.

Cytotoxicity assay. Two types of target cells $\left(1 \times 10^{5} / \mathrm{ml}\right)$ in a logarithmic growth phase, ILT2 $2^{\text {low } I L T} 3^{\text {low }}$ human well differentiated gastric cancer MKNI cells and ILT2 ${ }^{\text {high }}$ ILT $3^{\text {high }}$ undifferentiated gastric cancer HGC27 cells, were seeded in 96 well culture plates at $37^{\circ} \mathrm{C}$, in a $5 \% \mathrm{CO}_{2}$ incubator for $4 \mathrm{~h}$, respectively. Each well contained $100 \mu \mathrm{l}$ RPMI-1640 medium supplemented with $10 \%$ fetal bovine serum (FBS). Whereafter, NK92MI cells were added in a volume of $100 \mu 1$ at effector and target cell ratios of 10:1, 5:1, 2.5:1 and 1.25:1. Blank controls, target cell controls (T) and effector cell controls (E) were set synchronously. The cell mixtures were then incubated at $37^{\circ} \mathrm{C}$, in $5 \% \mathrm{CO}_{2}$ for $24 \mathrm{~h}$, after which $20 \mu \mathrm{l} \mathrm{MTT}(5 \mathrm{mg} / \mathrm{ml})$ was added and cultured for a further $4 \mathrm{~h}$. The absorbance was determined at $570 \mathrm{~nm}$ by an ELISA reader. The percentage of kill (\% kill) was calculated using the following equation: $\%$ kill $=\left[1-\left(\mathrm{OD}_{\mathrm{E}+\mathrm{T}}-\mathrm{OD}_{\mathrm{E}}\right) / \mathrm{OD}_{\mathrm{T}}\right] \times 100 \%$.

Immunohistochemistry. Immunohistochemical staining was performed using the biotin-streptavidin-peroxidase method with a Vectastain ABC kit (Invitrogen). Resected tissue specimens were collected and fixed in formalin, embedded in paraffin, and cut into $4-\mu \mathrm{m}$ serial sections. Sections were incubated with mouse anti-ILT2 and ILT3 antibodies (diluted 


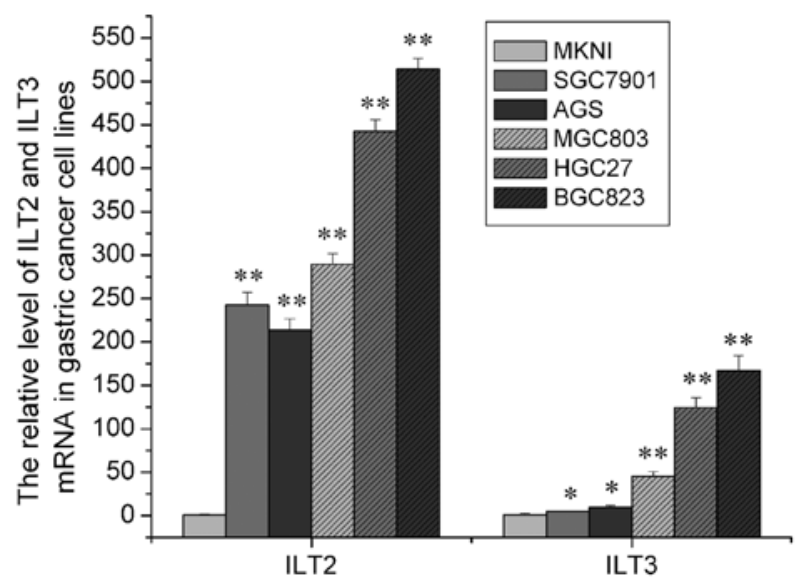

Figure 1. Expression of ILT2 and ILT3 mRNA in the gastric cancer cell lines. Expression of ILT2 and ILT3 at the level of mRNA increased with the decreased degree of gastric cancer cell differentiation. ${ }^{*} \mathrm{P}<0.05,{ }^{* *} \mathrm{P}<0.01$ by comparision with the well-differentiated gastric cancer cell line (MKN1).

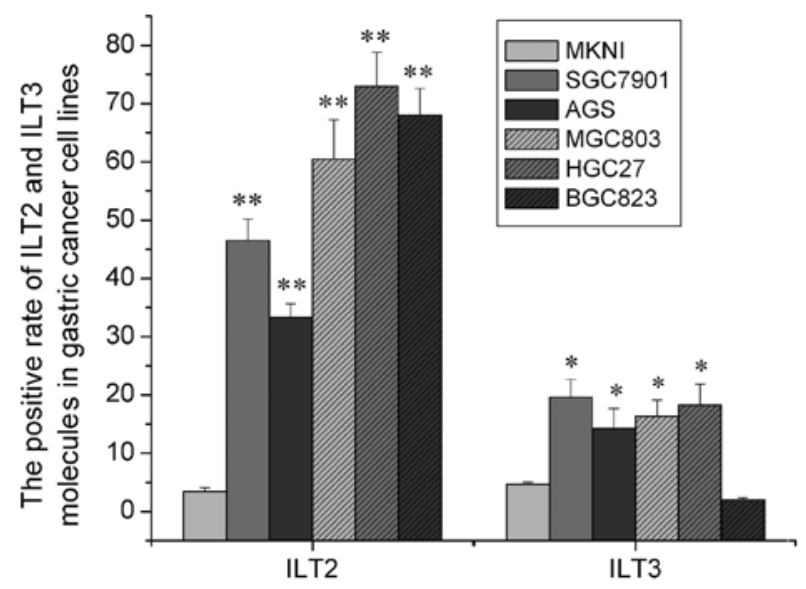

Figure 2. Expression of ILT2 and ILT3 protein in gastric cancer cell lines. The positive rates of ILT2 protein were related to the differentiation of the gastric cancer cells. However, the expression of ILT3 protein did not obviously vary in the gastric cancer cells with different degrees of differentiation. ${ }^{*} \mathrm{P}<0.05$, ${ }^{* * *} \mathrm{P}<0.01$ by comparision with the well-differentiated gastric cancer cell line (MKN1).

1:300) in a humidty chamber at $4^{\circ} \mathrm{C}$ overnight. After washing with PBS, the sections were incubated with biotinylated goat anti-mouse antibodies for $30 \mathrm{~min}$ and then washed three times with PBS, and then incubated with streptavidin-conjugated peroxidase for $30 \mathrm{~min}$. The sections were then visualized by incubation with 3,3'-diaminobenzidine solution ( $0.3 \%$ hydrogen peroxide and $0.05 \%$ 3,3'-diaminobenzidine) and stained with hematoxylin. Negative controls were carried out by substituting a normal mouse $\mathrm{IgG}$ for the primary antibody. Histological analysis was performed by two investigators simultaneously by microscopy without knowledge of the patient clinical records, and the number of ILT2- and ILT3-stained tumor cells among 1,000 tumor cells in each section was determined. Cell counts were performed at a magnification $\mathrm{x} 400$ in at least five fields in randomly selected tumor areas.

Statistical analysis. Statistical analysis was performed using SPSS 10.0. Comparison of the means between the two groups

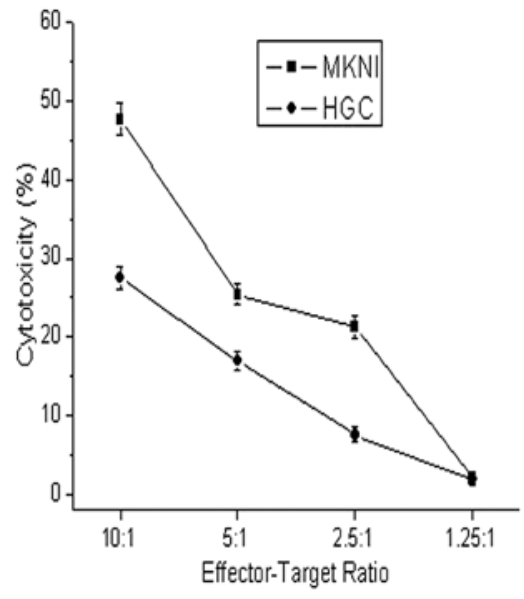

Figure 3. Killing activity of NK92MI to MKNI and HGC-27 with diverse effector-target ratios. The cytotoxicity of NK92MI to ILT2 ${ }^{\text {low }}$ ILT3 ${ }^{\text {low }}$ MKNI was stronger than that to ILT2 $2^{\text {high }}$ ILT $3^{\text {high }}$ HGC-27 at different effector-target ratios (except at 1.25:1). was different analyzed using the t-test, and comparison of the means among the groups was assayed by variance analysis and SNK test. The result of the immunohistochemistry was analyzed using the $\chi^{2}$ test, and the relationship between the expression of ILT2 and ILT3 and clinical parameters was assessed by the Fisher's test. Data were represented as the means \pm standard deviation. Values of $\mathrm{P}<0.05$ were considered to denote statistical signification.

\section{Results}

Expression of ILT2 and ILT3 mRNA in gastric cancer cells. We detected ILT2 and ILT3 mRNA expression in the 6 gastric cancer cell lines using FQ-PCR SYBR-Green I. The relative expression of ILT2 and ILT3 mRNA is shown in Fig. 1. Due to the absence of a negative standard control, we used the expression of ILT2 and ILT3 mRNA in the MKNI cell line as cardinal number. Relative expression of ILT2 and ILT3 mRNA in the other groups was derived from values compared with the cardinal number. As shown in Fig. 1, it was demonstrated that ILT2 and ILT3 mRNA expression increased along with increased differentiation, and the difference among them was significant $(\mathrm{P}<0.05)$.

Expression of ILT2 and ILT3 protein in gastric cancer cells (Fig. 2). The positive rate of ILT2 and ILT3 protein expression in the wel- differentiated gastric cancer cell line MKN1 was low, which was significantly different from the expression levels in the moderately or poorly differentiated gastric cancer cell lines and the undifferentiated tumor cell lines as well $(\mathrm{P}<0.05)$. Among the 6 gastric cancer cell lines, BCG823 hardly expressed the ILT3 protein while it expressed a high level of the ILT2 protein. The positive rates of ILT3 protein expression were lower than those of the ILT2 protein in the five cell lines (MKN1, SGC7901, AGC, MGC803 and HGC27), and expression of the ILT3 protein did not vary obviously between the moderately or the poorly differentiated and undifferentiated cell line $(\mathrm{P}>0.05)$. However, the positive rate of ILT2 protein expression in poorly differentiated and undifferentiated gastric 

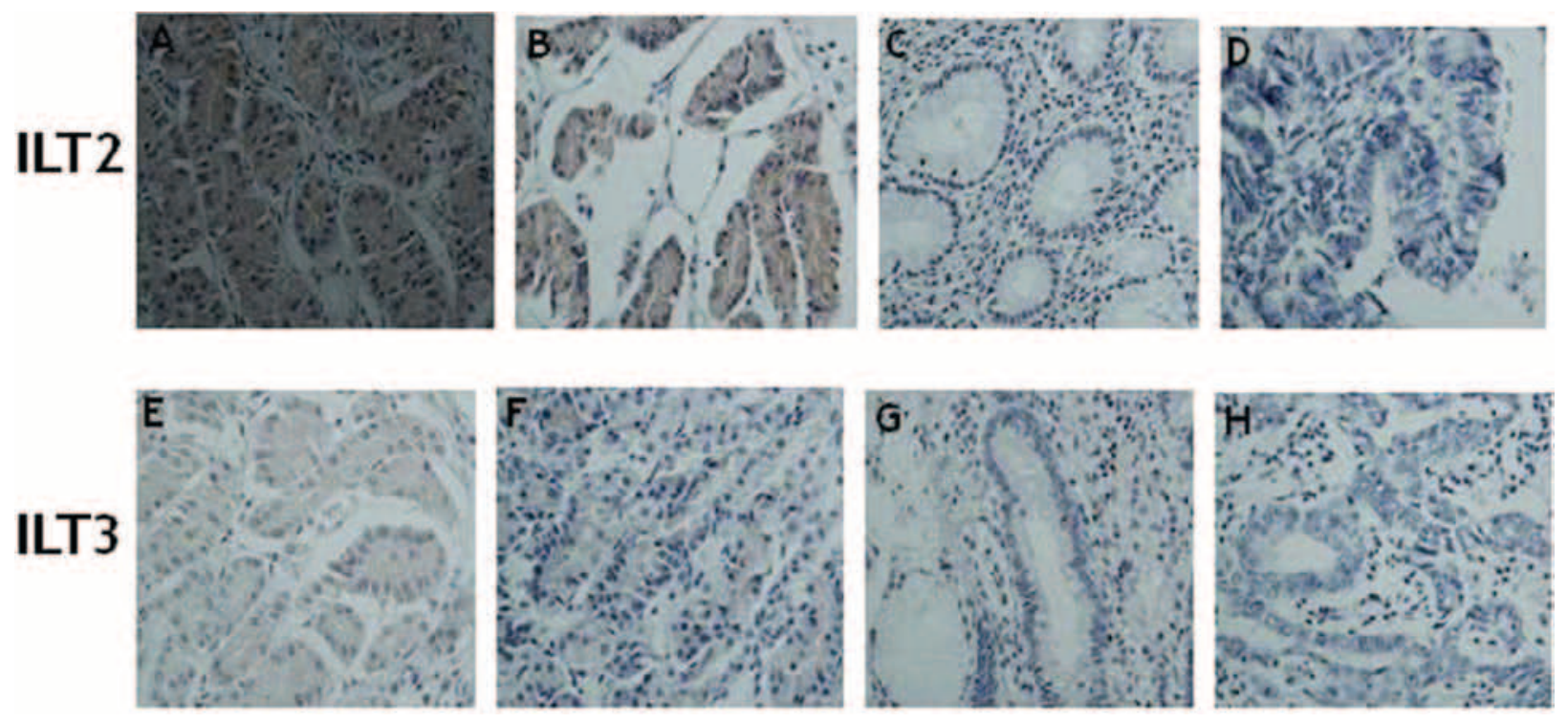

Figure 4. ILT2 and ILT3 immunohistochemical staining of (A and E) poorly differentiated gastric cancer, (B and F) moderately differentiated gastric cancer, ( $\mathrm{C}$ and $\mathrm{G}$ ) well-differentiated gastric cancer and (D and $\mathrm{H}$ ) normal gastric tissue. (Original magnification, $\mathrm{x} 400$ ) As shown above, ILT2 was expressed in gastric cancer tissues with diverse differentiation degrees and pathologic types, and the expression was correlated with differentiation degrees. Furthermore, there was barely any expression of ILT2 noted in the normal stomach tissue. However, no significantly statistical difference was achieved between ILT3 expression and the differentiation degree and size of the cancer tumors.

Table I. Relationship between ILT2 expression in the tumor cells and clinicopathological variables.

\begin{tabular}{|c|c|c|c|c|c|}
\hline \multirow[b]{2}{*}{ Clinicopathological variables } & \multirow[b]{2}{*}{ No. of patients } & \multicolumn{2}{|c|}{ ILT2 expression } & \multirow[b]{2}{*}{$\chi^{2}$} & \multirow[b]{2}{*}{ P-value } \\
\hline & & Negative & Positive & & \\
\hline Gender & & & & 0.002 & 0.968 \\
\hline Male & 37 & 14 & 23 & & \\
\hline Female & 13 & 5 & 8 & & \\
\hline Age (years) & & & & 0.085 & 0.771 \\
\hline$>60$ & 25 & 9 & 16 & & \\
\hline$\leq 60$ & 25 & 10 & 15 & & \\
\hline Tumor location & & & & 0.656 & 0.720 \\
\hline Ridge $1 / 3$ & 30 & 11 & 19 & & \\
\hline Medi 1/3 & 13 & 6 & 7 & & \\
\hline Bottom 1/3 & 7 & 2 & 5 & & \\
\hline Differentiation & & & & 4.089 & $0.043^{\mathrm{a}}$ \\
\hline Well/moderately & 20 & 11 & 9 & & \\
\hline Poorly & 30 & 8 & 22 & & \\
\hline Muscular infiltration & & & & 0.195 & 0.659 \\
\hline No & 14 & 6 & 8 & & \\
\hline Yes & 36 & 13 & 23 & & \\
\hline Metastasis & & & & 0.110 & 0.740 \\
\hline Negative & 17 & 7 & 10 & & \\
\hline Positive & 33 & 12 & 21 & & \\
\hline Tumor size & & & & 6.417 & $0.011^{\mathrm{a}}$ \\
\hline$\leq 5 \mathrm{~cm}$ & 31 & 16 & 15 & & \\
\hline$>5 \mathrm{~cm}$ & 19 & 3 & 16 & & \\
\hline
\end{tabular}

Well-differentiated gastric cancer included mastoid adenocarcinoma, well-differentiated tubular adenocarcinoma, and moderately differentiated adenocarcinoma; poorly differentiated cancer included poorly differentiated adenocarcinoma, signet ring cell cancer and Mucus cell carcinoma. ${ }^{\mathrm{a}} \mathrm{P}<0.05$. There was a significant relationship between ILT 2 expression and the differentiation and size of tumors . 
Table II. Relationship between ILT3 expression on tumor cells and clinicopathological variables.

\begin{tabular}{|c|c|c|c|c|c|}
\hline \multirow[b]{2}{*}{ Clinicopathological variables } & \multirow[b]{2}{*}{ No. of patients } & \multicolumn{2}{|c|}{ ILT3 expression } & \multirow[b]{2}{*}{$\chi^{2}$} & \multirow[b]{2}{*}{ P-value } \\
\hline & & Negative & Positive & & \\
\hline Gender & & & & 0.081 & 0.755 \\
\hline Male & 37 & 30 & 7 & & \\
\hline Female & 13 & 11 & 2 & & \\
\hline Age (years) & & & & 0.136 & 0.712 \\
\hline$>60$ & 25 & 20 & 5 & & \\
\hline$\leq 60$ & 25 & 21 & 4 & & \\
\hline Tumor location & & & & 2.414 & 0.087 \\
\hline Ridge $1 / 3$ & 30 & 24 & 6 & & \\
\hline Medi 1/3 & 13 & 11 & 2 & & \\
\hline Bottom $1 / 3$ & 7 & 6 & 1 & & \\
\hline Differentiation & & & & 0.203 & 0.652 \\
\hline Well/moderately & 20 & 17 & 3 & & \\
\hline Poorly & 30 & 24 & 6 & & \\
\hline Infiltration muscular & & & & 0.182 & 0.670 \\
\hline No & 14 & 12 & 2 & & \\
\hline Yes & 36 & 29 & 7 & & \\
\hline Metastasis & & & & 0.002 & 0.963 \\
\hline Negative & 17 & 14 & 3 & & \\
\hline Positive & 33 & 27 & 6 & & \\
\hline Tumor size & & & & 0.101 & 0.750 \\
\hline$\leq 5 \mathrm{~cm}$ & 31 & 25 & 6 & & \\
\hline$>5 \mathrm{~cm}$ & 19 & 16 & 3 & & \\
\hline
\end{tabular}

Well-differentiated gastric cancer included mastoid adenocarcinoma, well-differentiated tubular adenocarcinoma, moderately differentiated adenocarcinoma; poorly differentiated cancer included poorly differentiated adenocarcinoma, signet ring cell cancer and mucus cell carcinoma. No significant relationship was noted between ILT3 expression and clinicopathological variables.

cancer cells was much higher than that in the moderately and well-differentiated cancer cells $(\mathrm{P}<0.05)$.

Differential expression of ILT2 and ILT3 in gastric cancer cells affected NK92MI cytotoxicity. Here, we chose the ILT $2^{\text {low }}$ ILT $3^{\text {low }}$ well-differentiated gastric cancer cell line MKNI and the ILT2 $2^{\text {high }}$ ILT3 ${ }^{\text {high }}$ undifferentiated gastric cancer cell line HGC27 as target cells, and the NK92MI as effector cells. The cytotoxicity of NK92MI to MKNI and HGC27 was detected, respectively, using different effector-target ratios. The cytotoxicity of NK92MI to difference MKNI at effector-target ratios from 10:1 to 2.5:1 was stronger than that to HGC27 after $24 \mathrm{~h}$ of co-culture, and a significant difference was noted $(\mathrm{P}<0.05)$ (Fig. 3). We conclude that the different expression of ILT2 and ILT3 in gastric cancer cells influenced the killer activity of NK92MI cells.

Relationship between the expression of ILT2 and ILT3 in patients with gastric cancer and clinicopathologic variables. Expression of ILT2 and ILT3 in gastric cancer cells from 50 patient pathological tissues with diverse degrees of differentiation and pathological types were found to be dissimilar by immunohistochemistry, and the positive rate of ILT2 and ILT3 expression was $62.0 \%(31 / 50)$ and $18.0 \%$ (9/50), respectively, which indicates that there was a significant difference between ILT2 and ILT3 in the gastric cancer cells $(\mathrm{P}<0.01)$. ILT2 and ILT3 protein were expressed either in the cytoplasm or the cell membrane of the gastric cancer cells, but no ILT2 and ILT3 expression was noted in the normal stomach tissue (Fig. 4).

Further information concerning the pathological characteristics and the clinical data of these patients were analyzed (Tables I and II). It was demonstrated that there was no significant different between ILT2 and ILT3 expression and factors such as cancer origin, invasive depth and lymphatic metastasis $(\mathrm{P}>0.05)$. Yet, a distinct relationship was noted between ILT2 and the differentiation and size of the tumor. The positive rate of ILT2 expression was $73.3 \%$ (22/30) and 45\% (9/20), respectively, in the poorly differentiated cancers including adenocarcinoma, signet ring cell cancer and well differentiated cancer including mastoid adenocarcinoma, well- and moderately differentiated tubular adenocarcinoma $\left(\chi^{2}=4.089, \mathrm{P}<0.05\right)$. The positive rate of ILT2 expression was $84.2 \%$ when the tumor size was $>5 \mathrm{~cm}$, which was higher than that of $48.4 \%$ when the tumor size was $<5 \mathrm{~cm}\left(\chi^{2}=6.417, \mathrm{P}=0.011\right)$. Nevertheless, no significantly statistical relation was noted between ILT3 expression and the differentiation degree and the size of the tumors. 


\section{Discussion}

ILT2 and ILT3 belong to a family of inhibitory receptors, which are characterized by long cytoplasm tails that contain three immunoreceptor tyrosine-based inhibitory motifs (ITIMs) and either two or four homologous extracellular C-2 type Ig-like domains $(8,29,30)$. It has been suggested that the interaction of ILT2 or ILT3 with HLA-G inhibits the activation of $\mathrm{T}$ cells, natural killer cells and myelomonocytic cells $(9,31,32)$. They also regulate $\mathrm{CD} 8^{+} \mathrm{T}$ cell activation by blocking $\mathrm{CD} 8$ binding as well as by recruiting inhibitory molecules through their ITIM motifs (33). Recent studies have demonstrated that monocytes and dendritic cells (DCs) exposed to T suppressor or regulatory cells acquire a tolerogenic phenotype characterized by upregulation of ILT2 and ILT3 expression (34-36). Antigen-presenting cells (APCs), which express high levels of these receptors, can become tolerogenic and induce anergy in $\mathrm{CD}^{+} \mathrm{T}$ helper cells $(32,37)$. Then the antigen-presenting function of monocytes and DCs is modulated by the level of expression of ILT2 and ILT3. Studies have also shown that ILT3 on the surface of B lymphocytes is related to tumorspecific $\mathrm{T}$ lymphocyte tolerance in B-cell chronic lymphatic leukemia, and regardless of whether ILT3 was membrane (mILT3) or soluble (sILT3), they all had strong immunosuppressive activity (38). In addition, high expression of ILT2 and ILT3 was found to highly induce Th cells and CTLs into Treg and Ts cells, respectively, in vitro while ILT was expressed in DCs. CD8 ${ }^{+} \mathrm{CD} 28^{-}$Ts cells upregulated the expression of HLA-G in tumor cells, which result in immune escape $(25,39)$. Yet, no report exists to date concerning ILT2 and ILT3 expression in human tumor tissues and to our knowledge this is the first description of the expression of these molecules in primary gastric cancer.

Our studies demonstrate that ILT2 and ILT3 mRNA and protein were expressed to a different extent in the gastric cancer cells with different degrees of differentiation. Moreover, there was a significant relationship between the expression of ILT2 and ILT3 and the pathological grade of the gastric cancer. We also found that the cytotoxicity of NK cells against gastric cancer cells with different expression of ILT2 and ILT3 was distinct in vitro. It was previously reported that inhibitory receptors influence the function and state of T lymphocytes, NK cells and DCs, and regulate immunological tolerance $(40,41)$. Thus, we speculated that tumor cells express inhibitory receptors via certain pathways and affect the killer activity of immunocytes.

We found that ILT2 and ILT3 were expressed to some extent in the gastric cancer pathological tissues, and their expression in cancer tissues was characterized by a scattered pattern and was located in both the plasma membrane and the cytoplasm of the cancer cells. The intensity and positive rates of ILT2 were higher than that of ILT3, and the expression of ILT2 was obviously related to the differentiation and size of the tumors, which demonstrated that expression of this inhibitory receptor by the tumor cells restrained the immune response. Sun et al (42) discovered that ILT4 was expressed in non-small cell lung cancer cells in vitro as well. By assessing clinical pathological tissues, they also found that there was a significant relation between the expression of ILT4 and surrounding tumor infiltrating lymphocytes (TILs), which suggested that the tumor cells induced infiltrating lymphocyte tolerance by contacting them indirectly after upregulating inhibitory ILT4. In conclusion, our research indicates that ILT2 and ILT3 expression in gastric cancer cells and tissues may play an important role in tumor development, and ILT2 and ILT3 may be applied as targets for the diagnosis and therapy of gastric cancer. However, further research is needed to understand the specific mechanism.

\section{Acknowledgements}

This study was supported in part by grants from the Shandong Province Science Foundation for Key Programs (2008GG30002017 and 2010GSF10274) and the University Innovation Program from Jinan, Shandong Province (201004050).

\section{References}

1. Yonemura Y, Endou Y, Sasaki T, Hirano M, Mizumoto A, Matsuda T, Takao N, Ichinose M, Miura M and Li Y: Surgical treatment for peritoneal carcinomatosis from gastric cancer. Eur J Surg Oncol 36: 1131-1138, 2010.

2. Jemal A, Siegel R, Ward E, Hao Y, Xu J and Thun MJ: Cancer statistics, 2009. CA Cancer J Clin 59: 225-249, 2009.

3. KawaidaH,KonoK, Takahashi A,Sugai H,Mimura K,Miyagawa N, Omata H, Ooi A and Fujii H: Distribution of $\mathrm{CD}^{+}{ }^{+} \mathrm{CD} 25$ (high) regulatory T-cells in tumor-draining lymph nodes in patients with gastric cancer. J Surg Res 124: 151-157, 2005.

4. Gross $\mathrm{S}$ and Walden P: Immunosuppressive mechanisms in human tumors: Why we still cannot cure cancer. Immunol Lett 116: 7-14, 2008.

5. Hirokawa K, Utsuyama M, Ishikawa T, Kikuchi Y, Kitagawa M, Fujii Y, Nariuchi H, Uetake H and Sugihara K: Decline of T cellrelated immune functions in cancer patients and an attempt to restore them through infusion of activated autologous T cells. Mech Ageing Dev 130: 86-91, 2009.

6. Petty JK, He K, Corless CL, Vetto JT and Weinberg AD: Survival in human colorectal cancer correlates with expression of the T-cell costimulatory molecule OX-40 (CD134). Am J Surg 183: 512-518, 2002.

7. Tedla N, Lee CW, Borges L, Geczy CL and Arm JP: Differential expression of leukocyte immunoglobulin-like receptors on cordblood-derived human mast cell progenitors and mature mast cells. J Leukoc Biol 83: 334-343, 2008.

8. Gleissner CA and Dengler TJ: Induction of ILT expression on nonprofessional antigen presenting cells: clinical applications. Hum Immunol 70: 357-359, 2009.

9. Monsivais-Urenda A, Nino-Moreno P, Abud-Mendoza C, Baranda L, Layseca-Espinosa E, Lopez-Botet M and GonzalezAmaro R: Analysis of expression and function of the inhibitory receptor ILT2 (CD85j/LILRB1/LIR-1) in peripheral blood mononuclear cells from patients with systemic lupus erythematosus (SLE). J Autoimmun 29: 97-105, 2007.

10. Nakajima H, Samaridis J, Angman L and Colonna M: Cutting edge: human myeloid cells express an activating ILT receptor (ILT1) that associates with Fc receptor gamma-chain. J Immunol 162: 5-8, 1999.

11. Cella M, Dohring C, Samaridis J, Dessing M, Brockhaus M, Lanzavecchia A and Colonna M: A novel inhibitory receptor (ILT3) expressed on monocytes, macrophages, and dendritic cells involved in antigen processing. J Exp Med 185: 1743-1751, 1997.

12. Xu X, Zou P, Chen L, Jin G and Zhou H: IL-10 enhances promoter activity of ILT4 gene and up-regulates its expression in THP-1 cells. J Huazhong Univ Sci Technolog Med Sci 30: 594-598, 2010.

13. Wende H, Volz A and Ziegler A: Extensive gene duplications and a large inversion characterize the human leukocyte receptor cluster. Immunogenetics 51: 703-713, 2000.

14. Torkar M, Norgate Z, Colonna M, Trowsdale J and Wilson MJ: Isotypic variation of novel immunoglobulin-like transcript/killer cell inhibitory receptor loci in the leukocyte receptor complex. Eur J Immunol 28: 3959-3967, 1998

15. Chen Y, Chu F, Gao F, Zhou B and Gao GF: Stability engineering, biophysical, and biological characterization of the myeloid activating receptor immunoglobulin-like transcript 1 (ILT1/LIR-7/ LILRA2). Protein Expr Purif 56: 253-260, 2007. 
16. Banham AH, Colonna M, Cella M, Micklem KJ, Pulford K, Willis AC and Mason DY: Identification of the CD85 antigen as ILT2, an inhibitory MHC class I receptor of the immunoglobulin superfamily. J Leukoc Biol 65: 841-845, 1999.

17. Morel E and Bellon T: Amoxicillin conjugates to HLA class I molecules and interferes with signalling through the ILT2/LIR-1/ CD85j inhibitory receptor. Allergy 62: 190-196, 2007.

18. Colovai AI, Tsao L, Wang S, Lin H, Wang C, Seki T, Fisher JG, Menes M, Bhagat G, Alobeid B and Suciu-Foca N: Expression of inhibitory receptor ILT3 on neoplastic B cells is associated with lymphoid tissue involvement in chronic lymphocytic leukemia. Cytometry B Clin Cytom 72: 354-362, 2007.

19. Kim-Schulze S, Seki T, Vlad G, Scotto L, Fan J, Colombo RC, Liu J, Cortesini R and Suciu-Foca N: Regulation of ILT3 gene expression by processing of precursor transcripts in human endothelial cells. Am J Transplant 6: 76-82, 2006.

20. Ravetch JV and Lanier LL: Immune inhibitory receptors. Science 290: 84-89, 2000.

21. Chui CS and Li D: Role of immuno-lglobulin-like transcript family receptors and their ligands in suppressor T-cell-induced dendritic cell tolerization. Hum Immunol 70: 686-691, 2009.

22. Brown DP, Jones DC, Anderson KJ, Lapaque N, Buerki RA Trowsdale $\mathrm{J}$ and Allen RL: The inhibitory receptor LILRB4 (ILT3) modulates antigen presenting cell phenotype and, along with LILRB2 (ILT4), is upregulated in response to Salmonella infection. BMC Immunol 10: 56, 2009.

23. Pilsbury LE, Allen RL and Vordermeier M: Modulation of Toll-like receptor activity by leukocyte Ig-like receptors and their effects during bacterial infection. Mediators Inflamm 2010: 536478,2010

24. Vlad G, King J, Chang CC, Liu Z, Friedman RA, Torkamani AA and Suciu-Foca N: Gene profile analysis of CD8 ${ }^{+}$ILT3-Fc induced T suppressor cells. Hum Immunol 72: 107-114, 2011.

25. Vlad G, Cortesini R and Suciu-Foca N: CD8 ${ }^{+} \mathrm{T}$ suppressor cells and the ILT3 master switch. Hum Immunol 69: 681-686, 2008.

26. Zhang JY, Somani AK and Siminovitch KA: Roles of the SHP-1 tyrosine phosphatase in the negative regulation of cell signalling. Semin Immunol 12: 361-378, 2000.

27. Colonna M, Nakajima $\mathrm{H}$ and Cella M: A family of inhibitory and activating Ig-like receptors that modulate function of lymphoid and myeloid cells. Semin Immunol 12: 121-127, 2000.

28. Lefebvre S, Antoine M, Uzan S, McMaster M, Dausset J, Carosella ED and Paul P: Specific activation of the non-classical class I histocompatibility HLA-G antigen and expression of the ILT2 inhibitory receptor in human breast cancer. J Pathol 196 266-274, 2002

29. Fedoric B and Krishnan R: Rapamycin downregulates the inhibitory receptors ILT2, ILT3, ILT4 on human dendritic cells and yet induces $\mathrm{T}$ cell hyporesponsiveness independent of FoxP3 induction. Immunol Lett 120: 49-56, 2008.
30. Favier B, Lemaoult J, Lesport E and Carosella ED: ILT2/HLA-G interaction impairs NK-cell functions through the inhibition of the late but not the early events of the NK-cell activating synapse. FASEB J 24: 689-699, 2010.

31. Hofmeister V and Weiss EH: HLA-G modulates immune responses by diverse receptor interactions. Semin Cancer Biol 13: $317-323,2003$

32. Ju XS, Hacker C, Scherer B, Redecke V, Berger T, Schuler G, Wagner H, Lipford GB and Zenke M: Immunoglobulin-like transcripts ILT2, ILT3 and ILT7 are expressed by human dendritic cells and down-regulated following activation. Gene 331: $159-164,2004$

33. Shiroishi M, Tsumoto K, Amano K, Shirakihara Y, Colonna M, Braud VM, Allan DS, Makadzange A, Rowland-Jones S, Willcox B, Jones EY, van der Merwe PA, Kumagai I and Maenaka K: Human inhibitory receptors Ig-like transcript 2 (ILT2) and ILT4 compete with CD8 for MHC class I binding and bind preferentially to HLA-G. Proc Natl Acad Sci USA 100: 8856-8861, 2003.

34. Manavalan JS, Rossi PC, Vlad G, Piazza F, Yarilina A, Cortesini R, Mancini D and Suciu-Foca N: High expression of ILT3 and ILT4 is a general feature of tolerogenic dendritic cells. Transpl Immunol 11: 245-258, 2003.

35. Wu J and Horuzsko A: Expression and function of immunoglobulin-like transcripts on tolerogenic dendritic cells. Hum Immunol 70: 353-356, 2009.

36. Svajger U, Vidmar A and Jeras M: Niflumic acid renders dendritic cells tolerogenic and up-regulates inhibitory molecules ILT3 and ILT4. Int Immunopharmacol 8: 997-1005, 2008.

37. Suciu-Foca N and Cortesini R: Central role of ILT3 in the T suppressor cell cascade. Cell Immunol 248: 59-67, 2007.

38. Tamir I, Dal Porto JM and Cambier JC: Cytoplasmic protein tyrosine phosphatases SHP-1 and SHP-2: regulators of B cell signal transduction. Curr Opin Immunol 12: 307-315, 2000.

39. Taams LS, van Amelsfort JM, Tiemessen MM, Jacobs KM, de Jong EC, Akbar AN, Bijlsma JW and Lafeber FP: Modulation of monocyte/macrophage function by human $\mathrm{CD} 4^{+} \mathrm{CD} 25^{+}$regulatory T cells. Hum Immunol 66: 222-230, 2005.

40. Munitz A: Inhibitory receptors on myeloid cells: New targets for therapy? Pharmacol Ther 125: 128-137, 2010.

41. Leitner J, Grabmeier-Pfistershammer K and Steinberger P. Receptors and ligands implicated in human $\mathrm{T}$ cell costimulatory processes. Immunol Lett 128: 89-97, 2010.

42. Sun YP, Liu J, Gao P, Wang YS and Liu CY: Expression of Ig-like transcript 4 inhibitory receptor in human non-small cell lung cancer. Chest 134: 783-788, 2008. 